\title{
Associations of dairy cow behavior, barn hygiene, cow hygiene, and risk of elevated somatic cell count
}

\author{
T. J. DeVries, ${ }^{\star 1}$ M. G. Aarnoudse, ${ }^{\star}$ H. W. Barkema,† K. E. Leslie,‡ and M. A. G. von Keyserlingk§ \\ *Department of Animal and Poultry Science, University of Guelph, Kemptville Campus, 830 Prescott Street, Kemptville, ON, K0G 1J0, Canada \\ †Department of Production Animal Health, Faculty of Veterinary Medicine, University of Calgary, Calgary, Alberta, T2N 4N1, Canada \\ łDepartment of Population Medicine, Ontario Veterinary College, University of Guelph, 50 Stone Rd E, Guelph, ON, N1G 2W1, Canada \\ $\S$ Animal Welfare Program, Faculty of Land and Food Systems, University of British Columbia, 2357 Main Mall, Vancouver, BC, V6T 1Z4, Canada
}

\begin{abstract}
Poor dairy cow hygiene has been consistently associated with elevated somatic cell count (SCC) and the risk of subclinical mastitis. The objective of this study was to determine the associations between dairy cow standing and lying behavior, barn hygiene, cow hygiene, and the risk of experiencing elevated SCC. Lactating Holstein dairy cows $(\mathrm{n}=69 ; 86 \pm 51$ DIM; parity: $2.0 \pm 1.2$; means $\pm \mathrm{SD}$ ), kept in 1 of 2 groups, were monitored over a 4-mo period. Each group contained 61 \pm 1 (mean $\pm \mathrm{SD}$ ) cows over the study period; complete data were obtained from 37 and 32 animals within each respective group. Cows were housed in a sand-bedded, freestall barn with 2 symmetrical pens, each with a free cow traffic automatic milking system. To vary barn hygiene, in 4 consecutive 28-d periods, alley manure scrapers in each of the 2 pens were randomly assigned to frequencies of operation of $3,6,12$, and 24 times per day. During the last $7 \mathrm{~d}$ of each period, cow hygiene (upper leg/flank, lower legs, and udder; scale of $1=$ very clean to $4=$ very dirty) and stall hygiene (number of $0.15 \times 0.15-\mathrm{m}$ squares contaminated with manure in a $1.20 \times 1.65-\mathrm{m}$ grid) were recorded. Standing and lying behavior of the cows were collected during those days using data loggers. Individual-cow SCC was recorded at the beginning and end of each 28-d period. Elevated SCC was used as an indicator of subclinical mastitis; incidence of elevated SCC was defined as having a SCC $>200,000$ cells $/ \mathrm{mL}$ at the end of each 28 -d period, when SCC was $<100,000$ cells $/ \mathrm{mL}$ at the beginning of the period. Less frequent scraping of the barn alleys was associated with cows having poorer hygiene. Poor udder hygiene was associated with poor stall hygiene. Longer lying duration was associated with poor hygiene of the upper legs/flank and udder. Greater premilking standing duration was associated with poor udder hygiene and decreased frequency of
\end{abstract}

Received January 24, 2012.

Accepted June 1, 2012.

${ }^{1}$ Corresponding author: tdevries@uoguelph.ca lying bouts was associated with poor hygiene of the lower legs. Higher milk yield was associated with poor hygiene of the udder and lower legs; multiparous cows had poorer hygiene of the upper legs/flank and udder. Over the study period, 24 new cases of elevated SCC were detected. No associations existed for the risk of experiencing an elevated SCC with alley scraping frequency or cow behavior patterns. However, increased odds of occurrence of elevated SCC were noted for cows of lower milk yield as well as for multiparous cows. In summary, these results show that cow hygiene is affected by the standing and lying behavior of cows and by the cleanliness of the cow's environment. These findings emphasize the need for cows to be provided clean standing and lying environments. The results also show that frequent cleaning of barn alley floors will help improve cow hygiene.

Key words: hygiene, somatic cell count, behavior, dairy cow

\section{INTRODUCTION}

Primary sources of exposure of dairy cows to environmental pathogens causing mastitis include moisture and manure in the environment of the cow (Schreiner and Ruegg, 2002). It is, therefore, not surprising that poor hygiene has been demonstrated to be associated with higher SCC and the risk of subclinical mastitis in dairy cattle (Barkema et al., 1999; Schreiner and Ruegg, 2003; Reneau et al., 2005; Dohmen et al., 2010).

The lying environment of the cow has traditionally been considered the primary area where cows come in contact with moisture and manure and, thus, is a major factor affecting cow hygiene. Additional collection sites for moisture and manure are the alley floors located adjacent to the feeding area and in between rows of stalls where cows may walk, stand idle, or lie down. Magnusson et al. (2008) demonstrated that the use of mechanical scrapers on a slatted-floor barn improved alley hygiene and, in turn, improved cow udder hygiene. Freestall hygiene was also improved with use of scrapers, suggesting that less manure was being tracked 
into the stalls on the claws of the cows (Magnusson et al., 2008). These effects are likely greater in barns with solid-surface floors where manure is allowed to accumulate until it is scraped away. It is, therefore, reasonable to assume that in those situations, the longer that cows stand and walk in manure-laden alleys, the greater risk they have of becoming increasingly dirty, particularly when floors are not cleaned frequently.

Thus, the objective of this study was to determine the associations between standing and lying behavior, barn hygiene (of alley floors and freestalls), cow hygiene, and the risk of experiencing elevated SCC. It was hypothesized that those cows with longer standing durations would be at greater risk of becoming dirtier before lying down, particularly when alleys are less frequently cleaned, and that these cows will be at higher risk of experiencing an elevated SCC than cows that spend more time lying down.

\section{MATERIALS AND METHODS}

\section{Animals and Housing}

A study was conducted with 69 lactating Holstein dairy cows (31 primiparous and 38 multiparous; Table 1 ), kept in 1 of 2 groups. Cows were evenly distributed by parity and DIM between groups. Cows were followed from March to July 2011. Each group contained $61 \pm$ 1 (mean $\pm \mathrm{SD}$ ) cows over the study period. Complete data were obtained from 37 and 32 animals within each respective group, as some cows were dried off during the course of the experiment. All cows were kept on a commercial dairy farm (Williamsburg, Ontario, Canada) in a freestall barn with 2 symmetrical pens (as described in DeVries et al., 2011), separated by a drive-through feed alley. The barn was naturally ventilated with adjustable side-wall curtains and chimneys. Each pen contained an automatic milking system (AMS; Astronaut A2; Lely Industries NV, Maassluis, the Netherlands). Pens were arranged to allow for free cow traffic to the
AMS, with no directional gates or holding (restraint) areas. Each pen contained 60 freestalls configured in 2 rows. The 2 rows of stalls faced each another, were open at the front (head-to-head), and had a bed length of $2.55 \mathrm{~m}$. All freestalls measured $1.20 \mathrm{~m}$ wide center to center, and the neck rail was positioned $1.14 \mathrm{~m}$ above the stall bedding surface and $1.78 \mathrm{~m}$ from the rear curb. Stalls were deep bedded with $0.40 \mathrm{~m}$ of sand, cleaned and raked twice daily (at 0500 and $1700 \mathrm{~h}$ ), and were supplemented with new bedding every 2 wk. Rubber flooring was present on the crossover alleys and on the $2.0 \mathrm{~m}$ space in front of the length of the feed bunk. The rest of the floor space consisted of grooved concrete. Alley floors were cleaned using a cable-driven automated alley scraping system (GEA Houle Inc., Drummondville, Québec, Canada). Each pen had a post-and-rail feed barrier with $0.81 \mathrm{~m} /$ cow of feeding space and 3 water troughs (each $1.8 \times 0.5 \mathrm{~m}$; length $\times$ width). Barn lights automatically turned on at $0430 \mathrm{~h}$ and turned off at $2030 \mathrm{~h}$ for the entire study period. The average environmental temperature over the course of the study was $12.7 \pm 6.9^{\circ} \mathrm{C}$.

Cows had access to the AMS for 23 h daily (a 20-min milking equipment wash occurred at 0130, 1240, and $1800 \mathrm{~h}$ each day). With the exception of those cows that were $<35$ DIM, cows were allowed to access the AMS $6 \mathrm{~h}$ after the previous milking, unless a milking failure occurred, in which case cows were immediately eligible to be milked again. Cows $<35$ DIM were allowed to access the AMS $4 \mathrm{~h}$ after the previous milking. With the exception of those cows that were $>280$ DIM, all cows with $>12 \mathrm{~h}$ of elapsed time since the last milking were fetched and brought by the producer to the AMS at 0500 and $1700 \mathrm{~h}$ each day. Those cows $>280$ DIM with $>24$ h of elapsed time since the last milking were brought to the AMS at $0500 \mathrm{~h}$ each day. After every completed milking, cow teats were automatically sprayed with a postmilking disinfecting teat dip $(0.75 \%$ iodine; Dairyman's Defense Premier; Agrisan Specialty Chemical, Arthur, Ontario, Canada) and teat cups

Table 1. Descriptive statistics of data for cows $(n=69)$ included in the study

\begin{tabular}{lcccc}
\hline Variable & Mean & SD & Minimum & Maximum \\
\hline DIM $^{1}$ & 86 & 51 & 1 & 192 \\
Lactation no. & 2.0 & 1.2 & 1 & 5 \\
Milking frequency (no./d) & 2.6 & 0.6 & 1 & 6 \\
Milk yield (kg/d) & 35.3 & 8.6 & 16.8 & 92.3 \\
SCC (1,000 cells/mL) & 232 & 555 & 4.9 & 378 \\
Lying duration (h/d) & 11.4 & 2.0 & 31.8 & 20 \\
Lying bouts (no./d) & 8.4 & 2.2 & 5 & 199.3 \\
Lying bout length (min/bout) & 85.4 & 20.8 & 518 & 656 \\
Postmilking standing duration (min) & 77.1 & 36.1 & 7 & 6 \\
Premilking standing duration (min) & 87.1 & 38.0 & & 7.5 \\
\hline
\end{tabular}

${ }^{1}$ Data from cows at the beginning of the study period. 
were back flushed with hot water. All individual-cow milking-related data, including daily milking frequency, time of each milking, and yield per milking, were automatically collected and stored by the AMS.

All animals received mixed ration at the feed bunk, as well as supplemental concentrate at the AMS. The mixed ration was formulated according to the NRC (2001) nutrient requirement recommendations for highproducing dairy cows. The ration consisted of (on a DM basis) $25.2 \%$ corn silage, $34.6 \%$ haylage, $21.6 \%$ highmoisture corn, $9.5 \%$ protein and mineral supplement, $6.9 \%$ roasted soybeans, and $2.2 \%$ wheat straw. Cows were fed the ration once daily (at a level to achieve $3 \%$ orts) at $0730 \mathrm{~h}$. The ration was manually pushed up in the feed bunk 2 or 3 times daily. When feed was pushed up twice daily, it occurred at $1543 \mathrm{~h}( \pm 113 \mathrm{~min} ; \pm \mathrm{SD})$ and $2034 \mathrm{~h}( \pm 111 \mathrm{~min})$. When feed was pushed up 3 times daily, it occurred at $1416 \mathrm{~h}( \pm 117 \mathrm{~min}), 1748$ $\mathrm{h}( \pm 59 \mathrm{~min})$, and $2220 \mathrm{~h}( \pm 64 \mathrm{~min})$. Cows received varied amounts of concentrate in the AMS (0.5 to 4.5 $\mathrm{kg} / \mathrm{d}$ ) based on the individual cow milk yield and stage of lactation. The amount of concentrate apportioned at each milking was based on the elapsed time since the previous milking. Throughout the study all cows were managed according to the guidelines set by the Canadian Council on Animal Care (CCAC, 2009).

\section{Alley Floor Hygiene}

To vary barn alley floor hygiene, the frequency of alley scraping was altered in each of the pens. In 4 consecutive 28-d treatment periods, alley floor scrapers in each of the 2 pens within the barn were randomly assigned to frequencies of operation of 3 times/d (once every $8 \mathrm{~h}$ ), 6 times/d (once every $4 \mathrm{~h}$ ), 12 times/d (once every $2 \mathrm{~h}$ ), and 24 times/d (once every $1 \mathrm{~h}$ ).

\section{Standing and Lying Behavior}

Standing and lying behaviors were collected using data loggers (HOBO Pendant G Data Logger; Onset Computer Corp., Pocasset, MA). This device measures leg orientation at 1-min intervals, and allowed all of the standing and lying behavior data to be collected electronically (Ledgerwood et al., 2010). Prior to use, care was taken to synchronize the times of the AMS and the data loggers. These devices were attached to 1 of the hind legs of the cows using veterinary bandaging tape (Vetrap bandaging tape; 3M Canada, London, ON, Canada) for the last $7 \mathrm{~d}$ of each $28-\mathrm{d}$ period. Data collected were used to calculate standing and lying duration $(\mathrm{min} / \mathrm{d})$, bout frequency (no./d), and bout length (min/bout). Duration of postmilking standing (min) was calculated as the difference in time between the end of milking and the first recorded instance when the cow lay down following milking. The duration of premilking standing ( $\mathrm{min}$ ) was calculated as the difference in time between the start of milking and the time at which the cow stood up before milking.

\section{Cow Hygiene Data}

During each of the last $7 \mathrm{~d}$ of each 28 -d period, every cow was scored by 1 of 2 research technicians for cleanliness using a hygiene scoring system (http:// www.vetmed.wisc.edu/dms/fapm/fapmtools/4hygiene/ hygiene.pdf; Cook and Reinemann, 2007). Cows were scored on a 4 -point cleanliness scale $(1=$ very clean to $4=$ very dirty), evaluating separately the udder, lower legs, and upper legs/flank. Interobserver reliability was evaluated by comparing hygiene scores from 3 consecutive days assessed independently by the 2 observers; correlations averaged $( \pm \mathrm{SD}) 0.82 \pm 0.09$.

\section{Stall Hygiene}

Stall hygiene was assessed on each of the last $7 \mathrm{~d}$ (at 1600 h, before the p.m. stall maintenance) of each 28-d period using a previously developed methodology (Zdanowicz et al., 2004; Bernardi et al., 2009; Fregonesi et al., 2009). On each day, in 12 randomly selected stalls within each pen (6 stalls from each row in each pen), a $1.20 \times 1.65-\mathrm{m}$ wire grid, containing 88 equally sized squares $(0.15 \times 0.15 \mathrm{~m})$, was placed at the rear section of the stall closest to the alley and centered between the stall partitions. A hygiene score was allocated by counting the total number of grid squares containing any visible fecal material.

\section{Milk Sampling and Analysis}

Data on milk quality (SCC) was collected through regular DHI milk testing. The study began immediately after a regularly scheduled DHI milk testing; subsequent DHI milk tests were then scheduled to occur sometime during the last $7 \mathrm{~d}$ of each 28 - $\mathrm{d}$ period. For each sampling day, composite milk samples were automatically collected from each cow using a Lely Shuttle milking sampling unit (Lely Industries NV) connected to each AMS. Milk samples were then shipped overnight to a laboratory (CanWest DHI, Guelph, ON) where SCC analysis was conducted using the Fossomatic method (Fossomatic 4000 series; Foss Electric A/S, Hillerød, Denmark).

Elevated SCC (eSCC) was used as an indicator of subclinical mastitis (Dufour et al., 2011). An inci- 
dent (new) eSCC was defined as a cow having a SCC $>200,000$ cells $/ \mathrm{mL}$ at the end of each $28-\mathrm{d}$ period when SCC had been $<100,000$ cells $/ \mathrm{mL}$ at the beginning of that period (Dohoo and Leslie, 1991; Schepers et al., 1997; Schukken et al., 2003). Cows with SCC >100,000 cells $/ \mathrm{mL}$ at the beginning of any period were excluded (i.e., not considered at risk having an incident eSCC) because they may have been already developing or recovering from subclinical mastitis. Because cows had to have a SCC $<100,000$ cell $/ \mathrm{mL}$ at the beginning of any period to be considered at risk of a new eSCC, any cows experiencing a new eSCC during a period could not be considered at risk of becoming infected during the subsequent period. Thus, over the 4 periods, the maximum number of new eSCC any individual cow could develop would be 2. Sample size estimates to determine the required number of cows and treatment periods were conducted a priori using Power Analysis and Sample Size (PASS) software (NCSS LLC, Kaysville, UT), using the results of DeVries et al. (2011) for expected incidence rates of infection.

\section{Statistical Analysis}

Prior to analyses, all data were screened for normality using the UNIVARIATE procedure of SAS (SAS Institute, 2009). Cow SCC and stall hygiene scores were right skewed and, thus, were transformed by taking the natural logarithm. Hygiene, production, and behavioral data were summed across each of the 7-d observation periods for each cow. The associations of barn hygiene (alley floor scraping frequency and freestall hygiene) and cow behavior (independent variables) with hygiene scores of the upper legs/flank, udder, and lower legs (dependent variables) were analyzed with linear mixed models using the MIXED procedure of SAS (SAS Institute, 2009). The models included the random effects of group and cow within group. Univariable analyses were conducted for the fixed effects (independent variables) of alley scraper frequency, treatment period, parity (primiparous or multiparous cow), DIM, milking frequency and yield, measures of standing and lying behavior, and stall hygiene. Only associations with $P<1.10$ in this initial screening were included in multivariable linear regression models, with the exception of parity, which was considered a potential confounding variable. The CORR procedure of SAS was used to check for correlations between the kept explanatory variables. If 2 variables were highly correlated $(\mathrm{r}>0.8)$, the one with the lower $P$-value in the univariable analysis or the one with the most biologically plausible relationship (or both) was kept. Manual backward elimination of nonsignificant $(P>0.05)$ fixed effects was used and from the resultant models, plausible 2 -way interactions were examined and retained if $P<0.05$; only those significant results in the final models are further presented.

The association of barn hygiene (alley floor scraping frequency and freestall hygiene), cow hygiene, and cow behavior with the occurrence or nonoccurrence of a new eSCC was assessed using a random intercept mixed logistic model using the GLIMMIX procedure (distribution $=$ binomial and link $=$ logit $)$ of SAS (SAS Institute, 2009). As eSCC were assessed at the cow level, cow within group was considered random. Unconditional associations were estimated in the described model to screen all potential explanatory variables. The variables screened included alley scraper frequency; parity (primiparous or multiparous cow); postmilking and premilking standing duration; lying duration; lying bout frequency and length; milking frequency and yield; DIM; cow SCC at the beginning of the study; hygiene score of the lower legs, udder, and upper legs/ flank; and stall hygiene. For variables measured on a continuous scale, linearity of the relationship between the variable and the occurrence of a new eSCC was assessed by categorizing the continuous variable and visual inspection of plots of the odds ratio against mean values of the categories. Variables with $P \leq 0.20$ were retained for model building, with the exception of parity, which was considered a potential confounding variable. The CORR procedure of SAS was used to check for correlations between the kept explanatory variables. If 2 variables were highly correlated $(\mathrm{r}>0.8)$, the one with the lower $P$-value in the univariable analysis or the one with the most biologically plausible relationship (or both) was kept. Variables were then included in a multivariable analysis using the above mentioned model. Manual backward elimination of nonsignificant $(P>0.05)$ effects was used and from the resultant model, plausible 2 -way interactions were examined and retained if $P<0.05$; only those significant results in the final model are further presented.

\section{RESULTS AND DISCUSSION}

Descriptive statistics for the study cows and their behavior are found in Table 1. Cows were, on average, relatively early in lactation at the beginning of the study. Even though the study was conducted over a period of $112 \mathrm{~d}$, cows maintained a reasonably high level of production across that time period. The distribution of cow SCC at the beginning of the study period was right skewed, largely due to 10 of the study cows having a SCC >400,000 cells/mL; across cows, the geometric mean cow SCC was 73,400 cells $/ \mathrm{mL}$. It has previously been reported that the average geometric bulk tank SCC in the region that the study herd is located was 205,000 cells/mL (Olde Riekerink et al., 2008). This 
Table 2. Distribution $(\%)$ of and mean $( \pm \mathrm{SD})$ cow hygiene scores for cows across the study

\begin{tabular}{lcrrrr}
\hline & \multicolumn{4}{c}{ Hygiene score $^{1}$} & \\
\cline { 2 - 5 } Area & 1 & 2 & 3 & 4 & Mean hygiene score \\
\hline Upper leg/flank & 0.5 & 28.1 & 49.5 & 21.9 & $2.9 \pm 0.49$ \\
Lower legs & 0.0 & 0.3 & 18.0 & 81.7 & $3.8 \pm 0.20$ \\
Udder & 7.2 & 28.3 & 42.3 & 22.2 & $2.8 \pm 0.53$ \\
\hline
\end{tabular}

${ }^{1}$ Hygiene scores ranged from $1=$ very clean to $4=$ very dirty.

would suggest that the majority of study cows used started the study period with good udder health relative to the larger regional population.

The lying behavior observed (Table 1) compares well with data from other commercial freestall herds despite differences in technologies and methodologies used to capture and summarize this behavior. As comparative examples, Ito et al. (2009) reported a lying duration (mean $\pm \mathrm{SE}$ ) of $11.0 \pm 2.1 \mathrm{~h} / \mathrm{d}$, split into $9 \pm 3$ bouts $/ \mathrm{d}$ (mean $\pm \mathrm{SE}$ ), with a mean bout duration of $1.5 \pm 0.5$ h (mean \pm SE); Bewley et al. (2010) reported a lying duration (mean $\pm \mathrm{SD}$ ) of $10.5 \pm 2.1 \mathrm{~h} / \mathrm{d}$, split into 11.0 \pm 3.9 bouts/d (mean \pm SD); Gomez and Cook (2010) reported a lying duration (mean $\pm \mathrm{SD}$ ) of $11.9 \pm 2.4$ $\mathrm{h} / \mathrm{d}$, split into $12.9 \pm 6.6$ bouts/d (mean $\pm \mathrm{SD}$ ), with mean bout duration of $1.2 \pm 0.4 \mathrm{~h}$ (mean $\pm \mathrm{SD}$ ). Interestingly, data in the Ito et al. (2009) and Gomez and Cook (2010) studies were collected on parlor-milked, freestall-housed cows, whereas data collected by Bewley et al. (2010) also included cows milked by AMS. As previously observed in this study herd (DeVries et al., 2011), the average lying duration observed for AMSmilked cows was similar to parlor-milked cows, despite AMS cows not having to wait in a holding area before milking. Parlor-milked cows are typically brought to a holding area in a large group, where they are often forced to wait anywhere from $30 \mathrm{~min}$ to over $1 \mathrm{~h}$ before finally being milked (Cook and Nordlund, 2009). Although cows did not have to leave their pen to be milked in the present study, they did spend, on average, over $1 \mathrm{~h}$ standing before being milked. Unfortunately, we were not able to record what the cows were doing while they were standing. Thus, further research to investigate the actual time budgets and activities of AMS-milked cows is encouraged.

Distribution of, and average, hygiene scores of the different body parts across the study are listed in Table 2 . Hygiene scores of 3 and 4 were most frequently observed for the lower legs; greater than 4 times as many lower legs were scored as 4 compared with a score of 3 . Hygiene scores of 2,3 , and 4 were most frequently observed for the upper leg/flank and udder; a score of 3 was twice as common as scores of 2 and 4 for these body parts. These scores and their distribution indicate that the focal cows observed in this study had poor hygiene (i.e., were dirtier) compared with previous reports of cows managed under similar housing and milked conditions. DeVries et al. (2011) reported, for the same study herd used in this study, hygiene scores of 2 and 3 being most frequently observed for all 3 body part areas. In a survey of AMS-milked cows, using a similar hygiene scoring system, Dohmen et al. (2010) reported average scores of 2.5, 2.5, and 2.8 for the upper thighs, legs, and udder of the cows, respectively. In that study, similar to the DeVries et al. (2011) study, hygiene scores of 2 and 3 were most frequently observed across the body parts scored.

Descriptive statistics on stall hygiene scores across the different alley scraper frequencies are found in Table 3. Distributions of stall hygiene scores were all right skewed, the median scores were $4,2,2$, and 3 for alley scraper frequencies of 3, 6, 12, and 24 times per day, respectively. Scores of stall hygiene (i.e., no. of contaminated grid squares) of 7 (Zdanowicz et al., 2004), 4 (Bernardi et al., 2009), and 5 (Fregonesi et al., 2009) have previously been reported in studies using grid squares that were $2.25,2.81$, and 3.52 times smaller, respectively, than that used in the current study. This finding would suggest that the stalls in the current study were comparatively clean to these previous estimates in similarly bedded stalls.

The frequency of alley scraper operation was associated with cow hygiene (Table 4). Not surprisingly, less frequent scraper operation was associated with poorer hygiene of the upper legs/flank, udder, and lower legs. To our knowledge, this is the first study to show an effect of scraping frequency of solid-floored alleys on the hygiene of dairy cows. Magnusson et al. (2008) demonstrated that alley floor and cow hygiene could be improved by the use of mechanical scrapers on a slatted-floor barn. For solid-floor alleys, manure has a greater potential to accumulate on the floor and come in contact with cows. Thus, more frequent solid-floor cleaning would be predicted to have similar, if not greater, effects on improving cow hygiene as found in the current study. On the other hand, when solid floors 
Table 3. Mean, SD, minimum and maximum stall hygiene scores ${ }^{1}$ for the various imposed alley scraper frequencies

\begin{tabular}{lcccc}
\hline $\begin{array}{l}\text { Alley scraper } \\
\text { frequency (no./d) }\end{array}$ & Mean & SD & Minimum & Maximum \\
\hline 3 & 6.2 & 8.2 & 0 & 46 \\
6 & 4.8 & 6.0 & 0 & 39 \\
12 & 5.4 & 5.6 & 0 & 27 \\
24 & 5.2 & 6.3 & 0 & 30 \\
\hline${ }^{1}$ Number of fecal-contaminated squares in freestalls [out of 88 equally sized squares $(0.15 \times 0.15 \mathrm{~m})$ in a 1.20 \\
$\times 1.65$-m wire grid].
\end{tabular}

are cleaned with automatic alley scrapers, potential exists for much manure to build up in front of the scrapers (Cramer et al., 2009), causing the hooves of the cows to become soiled every time the cows are forced to walk over the alley scraper. Thus, even though frequent alley scraper operation may promote cleaner floors and cleaner cows in general, as observed in the current study, increased frequency of alley scraping may also result in cows placing their hooves in a larger pool of manure more frequently, which may, as hypothesized by Cramer et al. (2009), put them at greater risk of acquiring a hoof pathology. It is, thus, strongly encouraged that future work be conducted in this area.

In addition to the frequency of alley scraper operation, cow hygiene was also related to other factors, including standing and lying patterns, milk yield, parity, and stall hygiene (Table 4). Contrary to our hypothesis, greater lying duration was associated with poorer hygiene of upper legs/flank and udder. This finding is likely re- lated to the fact that these body parts may be in full, or partial, contact with the stall surface while the cow is lying down. While the cow is lying down, movements and shifting of her lying posture may increase the frequency at which different parts of her body contact the stall surface. Thus, if the freestall surface is soiled, then increased lying duration may increase exposure of those parts to manure and moisture. This is supported by the finding that poor udder hygiene was also related to poor freestall hygiene scores (Table 4). It could also be hypothesized that hygiene may deteriorate as cows are lying down if, and when, they splash manure from the alley floor on themselves with their tails. Further research to test these hypotheses is encouraged.

Hygiene scores of the upper legs/flank and udder were poorer in multiparous cows as compared with primiparous cows (Table 4). Reneau et al. (2005) similarly found that hygiene worsened as cows advanced in parity. As hypothesized by Reneau et al. (2005), older cows

Table 4. Final general linear model for factors associated with hygiene scores of the upper legs/flank, udder, and lower legs ${ }^{1}$

\begin{tabular}{|c|c|c|c|c|c|c|c|c|c|}
\hline Variable & \multicolumn{3}{|c|}{ Upper legs/flank } & \multicolumn{3}{|c|}{ Udder } & \multicolumn{3}{|c|}{ Lower legs } \\
\hline Frequency of alley scrapers ${ }^{3}$ & & & 0.002 & & & $<0.001$ & & & $<0.001$ \\
\hline 3 times/d & 0.22 & 0.059 & & 0.18 & 0.053 & & 0.14 & 0.028 & \\
\hline 6 times $/ \mathrm{d}$ & 0.11 & 0.058 & & 0.16 & 0.052 & & 0.03 & 0.027 & \\
\hline 12 times/d & 0.06 & 0.058 & & 0.02 & 0.052 & & 0.09 & 0.028 & \\
\hline Lying bouts (no./d) & - & - & - & - & - & - & -0.026 & 0.0059 & $<0.001$ \\
\hline Premilking standing duration (min) & - & - & - & 0.003 & 0.001 & 0.004 & - & - & - \\
\hline Milk yield (kg/d) & - & - & - & 0.011 & 0.004 & 0.007 & 0.003 & 0.0016 & 0.028 \\
\hline Parity & & & 0.02 & & & $<0.001$ & & & - \\
\hline 1 & Ref & - & & Ref & - & & - & - & \\
\hline$\geq 2$ & 0.19 & 0.084 & & 0.34 & 0.097 & & - & - & \\
\hline Stall hygiene ${ }^{5}$ & - & - & - & 0.42 & 0.065 & $<0.001$ & - & - & - \\
\hline
\end{tabular}

${ }^{1}$ Hygiene was scored on a scale of $1=$ very clean to $4=$ very dirty.

${ }^{2} \beta=$ estimated regression coefficient.

${ }^{3}$ Alley scrapers were varied to operate 3 times/d (once every 8 h), 6 times/d (once every $4 \mathrm{~h}$ ), 12 times/d (once every 2 h), or 24 times/d (once every $1 \mathrm{~h}$ ).

${ }^{4}$ Ref $=$ reference category.

${ }^{5}$ Stall hygiene $=$ natural logarithm of average number of fecal-contaminated squares in freestalls [out of 88 equally sized squares $(0.15 \times 0.15$ $\mathrm{m})$ in a $1.20 \times 1.65-\mathrm{m}$ wire grid]. 
are more likely to have larger and deeper udders, which are closer to the floor and more likely to be splashed with manure. Interestingly in the current study, even when corrected for this effect of parity, greater milk yield was associated with poor hygiene of the udder and lower legs (Table 4). This peculiar association has been previously reported. Ellis et al. (2007) reported that high and mid-yielding cows were less likely to be in a cleaner score category compared with all lactating cows. Similarly, Reneau et al. (2005) reported that cow hygiene improved as time from parturition increased; those researchers suggested, as did Ellis et al. (2007), that higher DMI associated with greater milk yield results in increased manure output. As hypothesized by DeVries et al. (2011), it is likely that the higherproducing cows in the current study ate more and had longer, larger meals, and thus were required to spend more time standing in the alley by the feed bunk. Nielsen et al. (2011) recently reported an association between greater standing duration and with the risk of having dirtier hind limbs. These authors attributed this result to increased exposure to slurry in the alleys compared with in the lying area. Although the current study results were unable to confirm this relationship, those cows with higher milk yield likely did spent an increased amount of their daily standing duration in the alley closest to the feed bunk; that alley would be expected to experience greater cow traffic and, thus, also greater manure accumulation. This hypothesis likely also explains the finding that greater premilking standing duration was associated with poor udder hygiene and lower lying bout frequency was associated with poor hygiene of lower legs (Table 4). DeVries et al. (2011) reported that AMS-milked cows that stood for longer periods of time before milking also had fewer lying bouts throughout the day, and that these behavioral patterns were also associated with higher milk yield. Thus, these behavioral patterns are likely related to the eating patterns of these cows, which necessitate these cows to spend more time standing in the alley by the feed bunk where they have a greater risk of becoming dirty. Unfortunately, the eating patterns and location of standing behavior of cows in the current study were not observed; thus, further research to investigate the association of these effects and cow hygiene is encouraged.

Of the 276 pairs of milk samples (i.e., consecutive DHI samples taken every $28 \mathrm{~d}$ ) taken, 94 pairs of milk samples were excluded due to high initial SCC (i.e., SCC on first sample within a pair was $>100,000$ cells/ $\mathrm{mL}$ ). As a result, 182 pairs of samples were enrolled for the analysis of eSCC. From these paired samples, 24 cases of new eSCC were detected. Thus, the incidence rate over the study period was 1.72 new eSCC/cowyear. Similar to that reported by DeVries et al. (2010, 2011), the relationship between average postmilking standing duration and incidence of eSCC was nonlinear (Figure 1). Thus, data were divided into meaningful categories $(0-60,60-90$, and $>90$ min), using knowledge of teat canal closure following milking (McDonald, 1975; Schultze and Bright, 1983). However, no associations existed for the risk of experiencing a new eSCC with these categories of postmilking standing duration. Similarly, no associations existed for the risk of experiencing a new eSCC with alley floor hygiene (i.e., alley scraping frequency), cow hygiene, or the other measures of lying behavior. Unconditional analyses showed that eSCC risk increased with cows of greater DIM, lower milk yield, and greater initial SCC, as well as when stalls were dirtier (Table 5). The final logistic model, however, revealed increased odds of occurrence of new eSCC for multiparous cows, as well as decreased odds of occurrence of new eSCC with cows of greater milk yield (Table 6). These associations are predictable, given that multiparous cows have been shown to be at greater risk of acquiring mastitis (Barkema et al., 1998) and that, even when controlling for parity, greater milk yield is associated with lower SCC due, in part, to the dilution effect that high yield has on cow SCC (Green et al., 2006).

The lack of any associations of cow hygiene and alley floor hygiene with risk of a new eSCC was somewhat surprising. Poor hygiene of dairy cows has been consistently reported to be associated with higher SCC and the risk of subclinical udder infection (Schreiner and Ruegg, 2003; Reneau et al., 2005; Dohmen et al., 2010). Similarly, better hygienic conditions on farm have been associated with lower herd bulk milk SCC (Barkema et al., 1999). As discussed above, cows in the present study had poor hygiene compared with previous reports of cows managed under similar housing and milked conditions. Across the study, the majority of cows $(71.4 \%$ for upper legs/flank, $99.7 \%$ for lower legs, and $64.5 \%$ for udder; Table 2) were scored with 1 of the 2 poorest scores (hygiene score of 3 or 4). Thus, even though these scores were affected by alley floor hygiene (Table 4), they were likely too high, on average, to influence any change in infectious pressure on the cows. It is also worthwhile to note that in a study by Köster et al. (2006), where associations between barn hygiene and SCC were explored in 80 German herds, alley hygiene was not related to SCC, whereas freestall hygiene was related to SCC. Similarly, freestall hygiene in the current study was found, in the unconditional analyses, to be related to the risk of a new eSCC. Thus, the effect that barn alley floor hygiene has on cow SCC 
Table 5. Unconditional estimates of association between explanatory factors and odds of having an incident elevated SCC

\begin{tabular}{lccc}
\hline Variable & $\begin{array}{c}\text { Percentage or mean } \\
\text { (SD) }\end{array}$ & $\begin{array}{c}\text { Odds ratio } \\
(95 \% \mathrm{CI})^{1}\end{array}$ & $P$-value \\
\hline Stall hygiene & & $1.21(0.79,1.86)$ & 0.20 \\
Milk yield (kg/d) & $1.7(0.32)$ & $0.58(0.34,1.00)$ & 0.04 \\
Parity & $36.6(8.6)$ & & 0.40 \\
1 & 44.9 & $\mathrm{Ref}^{3}$ & \\
$\geq 2$ & 55.1 & $1.49(0.58,3.80)$ & 0.19 \\
$\mathrm{DIM}^{4}$ & $115.8(55.4)$ & $1.48(0.85,2.14)$ & 0.08 \\
LnSCC $^{5}$ & $3.80(0.71)$ & & \\
\hline
\end{tabular}

${ }^{1}$ Odds ratio and $95 \%$ CI for 1-SD increase in continuous variable presented.

${ }^{2}$ Stall hygiene $=$ natural logarithm of average number of fecal-contaminated squares in freestalls [out of 88 equally sized squares $(0.15 \times 0.15 \mathrm{~m})$ in a $1.20 \times 1.65$-m wire grid].

${ }^{3}$ Ref $=$ reference category.

${ }^{4}$ Days in milk at the beginning of each observation period.

${ }^{5}$ Individual quarter natural logarithm SCC at the beginning of the study period.

is likely dependent on whether or not that hygiene also has an effect on the hygiene of the stalls that cows are lying in.

Based on previous studies (DeVries et al., 2010, 2011) it was predicted that the risk of a new eSCC would have been associated with cow behavior patterns, in particular the amount of time cows spend standing following milking. The observed relationship between postmilking standing duration and incidence of eSCC (Figure 1) was similar to the relationship observed by DeVries et al. (2011) between postmilking standing duration and incidence of CNS IMI. The lack of significant association in the present study is likely due, in part, to the high variability in incidence rate (see Figure 1) across the observed postmilking standing durations. Sample size estimates were conducted a priori based on results of DeVries et al. (2011). However, the use of eSCC as an indicator of infection (Dufour et al., 2011) in the current study is not as sensitive as using the results of bacteriological culture of quarter milk samples, as done in DeVries et al. (2011). Thus, to reduce variability and detect an association between postmilking standing

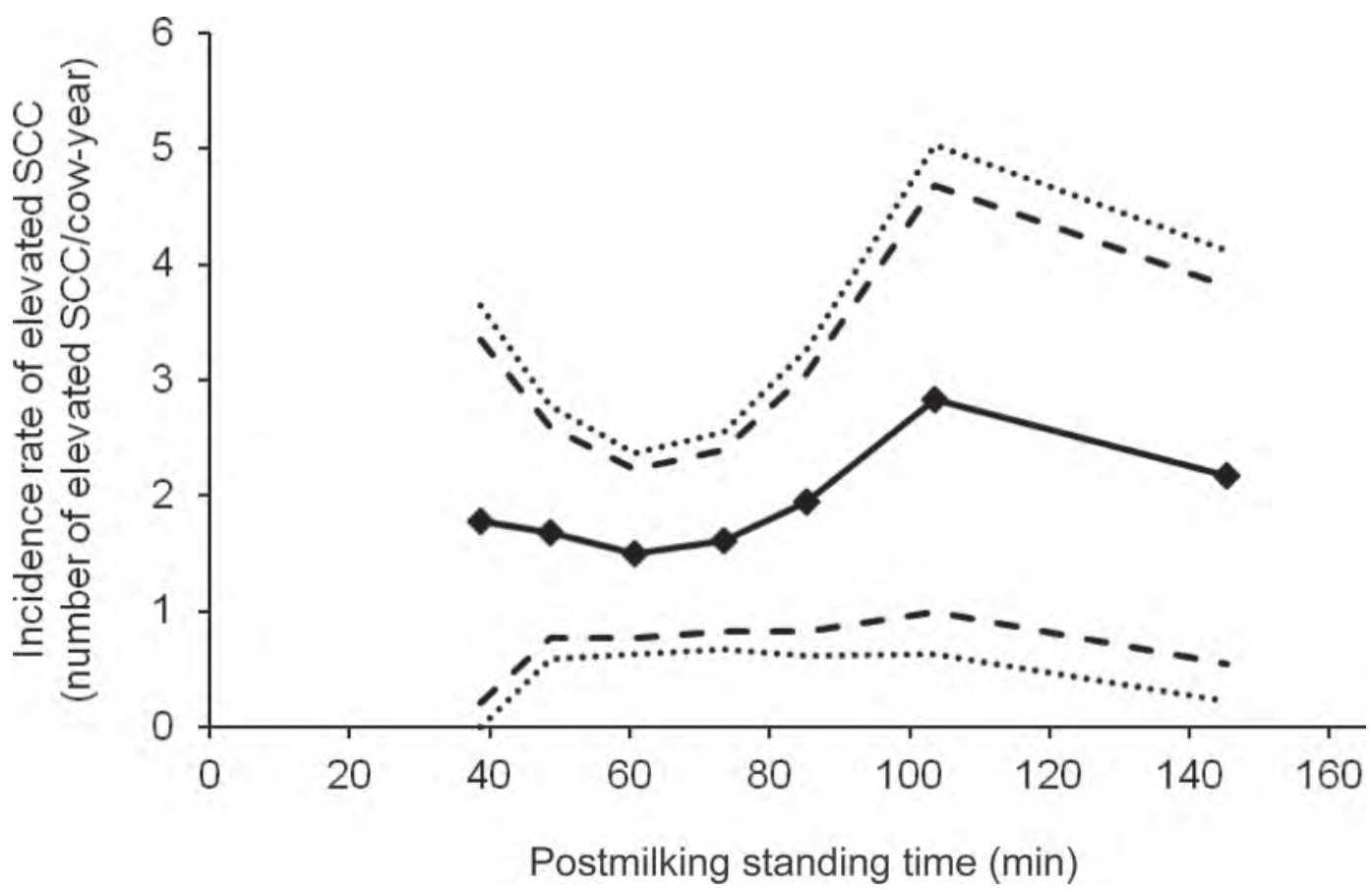

Figure 1. Moving average (with width of $30 \mathrm{~min}$ and increments of $15 \mathrm{~min}$ ) of incidence rate of elevated SCC across average postmilking standing duration. The elevated SCC incidence rates (solid line) with 90\% (dashed lines) and 95\% (dotted line) confidence limits are shown. 
Table 6. Final logistic regression model for factors associated with the incidence of elevated SCC

\begin{tabular}{lcccc}
\hline Variable & Coefficient & $\mathrm{SE}$ & Odds ratio $(95 \% \mathrm{CI})$ & $P$-value \\
\hline Intercept & 0.86 & 1.14 & - & - \\
Cow-level variance & 0.52 & 0.67 & $0.45(0.24,0.82)^{1}$ & 0.01 \\
Milk yield (kg/d) & -0.094 & 0.036 & $\operatorname{Ref}$ & 0.049 \\
Parity & $\operatorname{Ref}^{2}$ & Ref & $2.99(1.01,8.93)$ & \\
1 & 1.10 & 0.55 &
\end{tabular}

${ }^{1}$ Odds ratio and $95 \%$ CI for 1-SD increase in milk yield.

${ }^{2}$ Ref $=$ reference category.

duration and risk of a new eSCC, a study with a larger sample size is encouraged.

\section{CONCLUSIONS}

Dairy cow hygiene was associated with the standing and lying behavior of cows and with the cleanliness of the cow's environment. No associations of cow standing and lying behavior and cow and barn hygiene with the risk of experiencing eSCC were found. Cow hygiene may, in fact, deteriorate when cows spend long periods of time lying down, particularly when stalls are not clean. Further, cow hygiene may be compromised in those high milk-producing cows as well as in multiparous cows. These results emphasize the necessity for cows to be provided clean standing and lying environments. Last, the findings of this study indicate that increasing the frequency of barn alley floor cleaning will help improve cow hygiene.

\section{ACKNOWLEDGMENTS}

We thank Robert Byvelds and Brabantia Farms Inc. (Williamsburg, ON, Canada) for the use of the animals and facilities. We thank Megan Bruce and Mary Ellen Watters of the University of Guelph, Kemptville Campus (Kemptville, ON, Canada) for their technical help through the data collection and summarizing periods. Financial support for this research was received from the Dairy Farmers of Canada (Ottawa, ON, Canada), the Canadian Dairy Commission (Ottawa, ON, Canada), and Agriculture and Agri-Food Canada (Ottawa, ON, Canada) through the Canadian Bovine Mastitis Research Network (Saint-Hyacinthe, QC, Canada). This research was also supported through contributions from the Canadian Foundation for Innovation (Ottawa, ON, Canada) and the Ontario Research Fund (Ministry of Research and Innovation, Toronto, ON, Canada).

\section{REFERENCES}

Barkema, H. W., Y. H. Schukken, T. J. G. M. Lam, M. L. Beiboer, H. Wilmink, G. Benedictus, and A. Brand. 1998. Incidence of clinical mastitis in dairy herds grouped in three categories by bulk milk somatic cell counts. J. Dairy Sci. 81:411-419.

Barkema, H. W., J. D. van der Ploeg, Y. H. Schukken, T. J. G. M. Lam, G. Benedictus, and A. Brand. 1999. Management style and its association with bulk milk somatic cell count and incidence rate of clinical mastitis. J. Dairy Sci. 82:1655-1663.

Bernardi, F., J. Fregonesi, C. Winckler, D. M. Veira, M. A. G. von Keyserlingk, and D. M. Weary. 2009. The stall-design paradox: Neck rails increase lameness but improve udder and stall hygiene. J. Dairy Sci. 92:3074-3080.

Bewley, J. M., R. E. Boyce, J. Hockin, L. Munksgaard, S. D. Eicher, M. E. Einstein, and M. M. Schutz. 2010. Influence of milk yield, stage of lactation and body condition on dairy cattle lying behaviour using an automated activity monitoring sensor. J. Dairy Res. 77:1-6.

CCAC (Canadian Council on Animal Care). 2009. Guidelines on: The care and use of farm animals in research, teaching and testing. Canadian Council on Animal Care, Ottawa, ON, Canada.

Cook, N. B., and K. V. Nordlund. 2009. The influence of the environment on dairy cow behavior, claw health and herd lameness dynamics. Vet. J. 179:360-369.

Cook, N. B., and D. Reinemann. 2007. A toolbox for assessing cow, udder and teat hygiene. Pages 31-43 in Proc. NMC. Annu. Mtg. National Mastitis Council (NMC) Inc., Verona, WI.

Cramer, G., K. D. Lissemore, C. L. Guard, K. E. Leslie, and D. F. Kelton. 2009. Herd-level risk factors for seven different foot lesions in Ontario Holstein cattle housed in tie stalls or free stalls. J. Dairy Sci. 92:1404-1411.

DeVries, T. J., J. A. Deming, J. Rodenburg, G. Seguin, K. E. Leslie, and H. W. Barkema. 2011. Association of standing and lying behavior patterns and incidence of intramammary infection in dairy cows milked with an automated system. J. Dairy Sci. 94:3845-3855.

DeVries, T. J., S. Dufour, and D. T. Scholl. 2010. Relationship between feeding strategy, lying behavior patterns, and incidence of intramammary infection in dairy cows. J. Dairy Sci. 93:1987-1997.

Dohmen, W., F. Neijenhuis, and H. Hogeveen. 2010. Relationship between udder health and hygiene on farms with an automatic milking system. J. Dairy Sci. 93:4019-4033.

Dohoo, I. R., and K. E. Leslie. 1991. Evaluation of changes in somatic cell counts as indicators of new intramammary infections. Prev. Vet. Med. 10:225-237.

Dufour, S., A. Fréchette, H. W. Barkema, A. Mussell, and D. T. Scholl. 2011. Effect of udder health management practices on herd somatic cell count. J. Dairy Sci. 94:563-579.

Ellis, K. A., G. T. Innocent, M. Mihm, P. Cripps, W. G. Mclean, C. V. Howard, and D. Grove-White. 2007. Dairy cow cleanliness and milk quality on organic and conventional farms in the UK. J. Dairy Res. 74:302-310.

Fregonesi, J. A., M. A. G. von Keyserlingk, C. B. Tucker, D. M. Veira, and D. M. Weary. 2009. Neck-rail position in the free stall affects standing behavior and udder and stall cleanliness. J. Dairy Sci. 92:1979-1985.

Gomez, A., and N. B. Cook. 2010. Time budgets of lactating dairy cattle in commercial freestall herds. J. Dairy Sci. 93:5772-5781.

Green, L. E., Y. H. Schukken, and M. J. Green. 2006. On distinguishing cause and consequence: Do high somatic cell counts lead to 
lower milk yield or does high milk yield lead to lower somatic cell count? Prev. Vet. Med. 76:74-89.

Ito, K., D. M. Weary, and M. A. G. von Keyserlingk. 2009. Lying behavior: Assessing within- and between-herd variation in free-stallhoused dairy cows. J. Dairy Sci. 92:4412-4420.

Köster, G., B.-A. Tenhagen, and W. Heuwieser. 2006. Factors associated with high milk test day somatic cell count in large dairy herds in Brandenburg. I: Housing conditions. J. Vet. Med. Ser. A 53:134-139.

Ledgerwood, D. N., C. Winckler, and C. B. Tucker. 2010. Evaluation of data loggers, sampling intervals, and editing techniques for measuring the lying behavior of dairy cattle. J. Dairy Sci. 93:5129-5139.

Magnusson, M., A. H. Herlin, and M. Ventorp. 2008. Effect of alley floor cleanliness on free-stall and udder hygiene. J. Dairy Sci. 91:3927-3930.

McDonald, J. S. 1975. Radiographic method for anatomic study of the teat canal: Changes between milking periods. Am. J. Vet. Res. $36: 1241-1242$.

NRC. 2001. Nutrient Requirements of Dairy Cattle. 7th rev. ed. Natl. Acad. Sci., Washington, DC.

Nielsen, B. H., P. T. Thomsen, and J. T. Sørensen. 2011. Identifying risk factors for poor hind limb cleanliness in Danish loose-housed dairy cows. Animal 5:1613-1619.

Olde Riekerink, R. G. M., H. W. Barkema, D. F. Kelton, and D. T. Scholl. 2008. Incidence rate of clinical mastitis on Canadian dairy farms. J. Dairy Sci. 91:1366-1377.
Reneau, J. K., A. J. Seykora, B. H. Heins, M. I. Endres, R. J. Farnsworth, and R. F. Bey. 2005. Association between hygiene scores and somatic cell scores in dairy cattle. J. Am. Vet. Med. Assoc. 227:1297-1301.

SAS Institute. 2009. SAS User's Guide: Statistics. Version 9.2. SAS Institute Inc., Cary, NC.

Schepers, A. J., T. J. G. M. Lam, Y. H. Schukken, J. B. M. Wilmink, and W. J. A. Hanekamp. 1997. Estimation of variance components for somatic cell counts to determine thresholds for uninfected quarters. J. Dairy Sci. 80:1833-1840.

Schreiner, D. A., and P. L. Ruegg. 2002. Effects of tail docking on milk quality and cow cleanliness. J. Dairy Sci. 85:2503-2511.

Schreiner, D. A., and P. L. Ruegg. 2003. Relationship between udder and leg hygiene scores and subclinical mastitis. J. Dairy Sci. $86: 3460-3465$.

Schukken, Y. H., D. J. Wilson, F. Welcome, L. Garrison-Tikofsky, and R. N. Gonzalez. 2003. Monitoring udder health and milk quality using somatic cell counts. Vet. Res. 34:579-596.

Schultze, W. D., and S. C. Bright. 1983. Changes in penetrability of bovine papillary duct to endotoxin after milking. Am. J. Vet. Res. 44:2373-2375.

Zdanowicz, M., J. A. Shelford, C. B. Tucker, D. M. Weary, and M. A. G. von Keyserlingk. 2004. Sand and sawdust bedding affect bacterial populations on teat ends of dairy cows housed in freestalls. J. Dairy Sci. 87:1694-1701. 